\title{
Antibacterial activity of the sponge Suberites domuncula and its primmorphs: potential basis for epibacterial chemical defense
}

\author{
Narsinh L. Thakur ${ }^{1,2}$, Ute Hentschel ${ }^{3}$, Anatoli Krasko' ${ }^{1}$, Christian T. Pabel ${ }^{3}$, \\ Arga C. Anil ${ }^{2}$, Werner E. G. Müller ${ }^{1, *}$ \\ ${ }^{1}$ Institut für Physiologische Chemie, Abteilung Angewandte Molekularbiologie, Universität Mainz, Duesbergweg 6, \\ 55099 Mainz, Germany \\ ${ }^{2}$ Marine Corrosion \& Materials Research Division, National Institute of Oceanography, Dona Paula, 403004 Goa, India \\ ${ }^{3}$ Institut für Molekulare Infektionsbiologie, Universität Würzburg, Röntgenring 11, 97070 Würzburg, Germany
}

\begin{abstract}
The epibacterial chemical defense of the marine sponge Suberites domuncula was explored by screening sponge extract, sponge primmorph (3-D aggregates containing proliferating cells) extract and sponge-associated as well as primmorph-associated bacteria for antibacterial activity. 16S rDNA sequencing revealed that the antimicrobially active bacteria belonged to the $\alpha$ - and $\gamma$ subdivisions of Proteobacteria ( $\alpha$-Proteobacterium MBIC 3368, Idiomarina sp. and Pseudomonas sp., respectively). Moreover, a recombinant perforin-like protein was cloned from $S$. domuncula that displayed strong antibacterial activity. Based on these observations, it is proposed that the sponge may be provided with a direct (by producing antibacterial metabolites) as well as an indirect (with the help of associated bacteria) epibacterial defense.
\end{abstract}

KEY WORDS: Sponges · Primmorphs $\cdot$ Chemical defense $\cdot$ Antibacterial $\cdot$ Perforin-like protein Resale or republication not permitted without written consent of the publisher

\section{INTRODUCTION}

Sponges (Porifera), being evolutionarily ancient, multicellular, sessile organisms, inhabit every type of marine benthic environment. Particularly certain demosponges contain large numbers of bacteria that can amount to $40 \%$ of the biomass of the animal (Vacelet 1975), which may exceed the bacterial concentration of the seawater by 2 to 3 orders of magnitude (Friedrich et al. 2001). Sponges are thought to live in symbiosis with bacteria (Rützler 1985, Wilkinson 1992, Althoff et al. 1998, Haygood et al. 1999); however, the molecular basis for the proposed relationship is not well understood. Sponges are filter-feeders that pump large volumes of water through a unique and highly vascularized canal system (Bergquist 1978). Nutrients are acquired by phagocytosis of bacteria that are removed from the water column. Since typical seawater contains on average 1 to $5 \times 10^{6}$ bacteria $\mathrm{ml}^{-1}$, sponges potentially face problems such as clogging of the canal system, formation of biofims and fouling of their surfaces.
The surfaces of the marine sponge Suberites domuncula (Demospongiae, Hadromerida, Suberitidae) are noticeably free from epibionts. To investigate the epibacterial chemical defense of $S$. domuncula, 3 different approaches were pursued: (1) a classical chemistry approach by testing organic extract of the sponge and sponge primmorphs for antibacterial activity; (2) a classical microbiological approach by screening sponge- and primmorph-associated bacteria for antibacterial activity; and (3) a molecular biological approach by cloning and recombinant expression of a perforin-like protein. The findings are discussed in light of the epibacterial chemical defense strategies of S. domuncula.

\section{MATERIALS AND METHODS}

Sponge collection. Suberites domuncula sponges were collected from depths of between 30 and $40 \mathrm{~m}$, from the northern Adriatic, near Rovinj, Croatia 
$\left(45^{\circ} 07^{\prime} \mathrm{N}, 13^{\circ} 39^{\prime} \mathrm{E}\right)$, by SCUBA diving. They were transported in water-cooled containers and kept in recirculating seawater aquaria in Mainz, Germany, at a temperature of $17^{\circ} \mathrm{C}$ under continuous aeration.

Sponge primmorph culture. Primmorphs were obtained from dissociated cells of Suberites domuncula as described before (Müller et al. 1999). To remove epibacterial flora, the single cells were treated with antibiotics (100 IU ml- of penicillin and $100 \mathrm{\mu g} \mathrm{ml}^{-1}$ of streptomycin) as described earlier (Müller et al. 1999). The primmorphs were cultivated in seawater (Sigma), supplemented with $0.2 \%$ of RPMI1640-medium and $60 \mu \mathrm{M}$ silicate in the presence of antibiotics (Krasko et al. 2000). Primmorphs were used for the experiments $7 \mathrm{~d}$ (for bacteria isolation) or $26 \mathrm{~d}$ (for the preparation of organic extracts) after transfer of the cells into seawater.

Bacterial isolation. The surfaces of 3 aquariummaintained sponges were swabbed with a sterile cotton tip applicator which was then placed into $10 \mathrm{ml}$ of sterile seawater (Wahl et al. 1994). Following mixing and serial dilution, $3 \times 100 \mu$ of each dilution were plated on B1 medium $(0.25 \%$ peptone, $0.15 \%$ yeast extract, $0.15 \%$ glycerol, $1.6 \%$ agar, $100 \%$ seawater) (Newbold et al. 1999). Six bacterial isolates were obtained that were subsequently named SB1 to SB6.

Sponge vicinity bacteria were isolated from microfilms and developed on aluminum, glass, copper and acrylic panels that had been positioned in the immediate vicinity of sponge in aquarium. In addition, bacteria were also isolated from aquarium seawater. Altogether, 8 bacterial isolates were obtained from the sponge vicinity and were subsequently named VB1 to VB8.

Bacteria were isolated from $7 \mathrm{~d}$ old primmorphs which were 3 to $5 \mathrm{~mm}$ in diameter. Following repeated washing in sterile seawater, the primmorphs were squeezed in $10 \mathrm{ml}$ sterile seawater using sterile forceps. Of this suspension, $6 \times 100 \mu \mathrm{l}$ was plated on B1 agar and plates were incubated at $30^{\circ} \mathrm{C}$ for 24 to $72 \mathrm{~h}$. As a control, the sterile seawater from the last washing step was plated. These control plates were incubated at $30^{\circ} \mathrm{C}$ for up to $8 \mathrm{~d}$ and no bacterial growth was observed. Two bacterial isolates (PB1 and PB2) were obtained from the primmorphs.

Preparation of organic extracts. Sponge specimens $(50 \mathrm{~g})$ were cut into small pieces and placed in $200 \mathrm{ml}$ mixture of methanol:dichloromethane (1:1). After $24 \mathrm{~h}$, extract was decanted and collected for analysis. Following triplicate extraction, the extracts were pooled, filtered and concentrated in a rotary evaporator. Sponge primmorphs ( $26 \mathrm{~d}$ old, 1 to $2 \mathrm{~g}$ ) were washed with sterile seawater to remove antibiotics used in the media. Primmorphs were also extracted as described above.

Sponge- and primmorphs-associated bacteria were extracted in n-butanol following a method of Elyakov et al. (1996). Bacterial isolates were inoculated into conical flasks ( 1 l capacity) with $500 \mathrm{ml}$ cultural broth. The culture broth contained peptone $(2.5 \mathrm{~g}), \mathrm{K}_{2} \mathrm{HPO}_{4}$ $(0.1 \mathrm{~g})$, yeast extract $(1.25 \mathrm{~g})$, glucose $(0.5 \mathrm{~g}), \mathrm{MgSO}_{4}$ $(0.1 \mathrm{~g})$, seawater $(250 \mathrm{ml})$ and distilled water $(250 \mathrm{ml})$; the $\mathrm{pH}$ was adjusted to between 7.2 and 7.5. The flasks were incubated at $30^{\circ} \mathrm{C}$ for $3 \mathrm{~d}$ with shaking (100 rpm). After addition of $150 \mathrm{ml}$ of $\mathrm{n}$-butanol, the mixtures were kept at $40^{\circ} \mathrm{C}$ for $24 \mathrm{~h}$, stirred for $20 \mathrm{~min}$, centrifuged and the butanol layer was evaporated. Dry residue was stored below $5^{\circ} \mathrm{C}$ until further use.

Antibacterial assays. Antibacterial activities were tested in triplicate using the standard paper disc diffusion method. Concentrations of $500 \mu \mathrm{g} \mathrm{disc}^{-1}$ of sponge extract, $250 \mu \mathrm{g} \mathrm{disc}^{-1}$ of primmorphs extract and $500 \mu \mathrm{g}$ $\operatorname{disc}^{-1}$ of bacterial extracts were applied to sterile paper discs (6 $\mathrm{mm}$ in diameter). The solvent was evaporated before they were placed onto agar plates that had been seeded with reference bacterial strains. The diameter of the inhibition zones (diameter of inhibition zone minus diameter of disc) was measured in $\mathrm{mm}$ after incubation at $30^{\circ} \mathrm{C}$ for $24 \mathrm{~h}$. Solvent control discs without extract were prepared in the same manner and were never observed to inhibit bacterial growth.

Phylogenetic identification of bacteria. PCR amplification, cloning, sequencing and phylogenetic analysis of the microbial isolates (having antibacterial activity) from Suberites domuncula and its primmorphs was carried out as described previously (Hentschel et al. 2001). The obtained sequences were aligned using the ABI prism Auto assembler v. 2.1 software (Perkin Elmer) and entered into the BLAST and ARB 16S rDNA sequence database (see www.arb-home.de).

Cloning and expression of a perforin-like protein from Suberites domuncula. The cDNA (SDPFL) encoding the perforin-like protein, PFL_SD, was identified by differential display of mRNA in $6 \mathrm{~d}$ old primmorphs. A $200 \mathrm{bp}$ fragment was obtained which was used to screen the $S$. domuncula cDNA library (Kruse et al. 1997). One type of insert with a size of $839 \mathrm{nt}$ (termed SDPFL) was sequenced using an automatic DNA sequencer (Li-Cor 4200). The sequences were analyzed using computer programs BLAST and FASTA. The prediction of domains was performed using the ISREC server. The potential transmembrane region was predicted according to Rao \& Argos (1986).

The recombinant perforin-like protein was prepared in Escherichia coli as a fusion protein. The coding part of the clone from aa ${ }_{1}$ to $\mathrm{aa}_{198}\left(\mathrm{nt}_{31}\right.$ to $\left.\mathrm{nt}_{624}\right)$ was used for expression in E. coli. The cDNA was inserted into the bacterial oligohistidine expression vector pQE-30 (Qiagen) via the BamHI (5'-end) and the HindIII (3'end). E. coli was transformed with this plasmid and expression of fusion protein was induced for $12 \mathrm{~h}$ at $37^{\circ} \mathrm{C}$ with $1 \mathrm{mM}$ isopropyl 1 -thio- $\beta$-D-galactopyra- 
noside (IPTG) (Cariello et al. 1982). The fusion protein was extracted and purified using the BugBuster Protein Extraction Reagent (Novagen). The purity of the material was checked on $12 \%$ polyacrylamide gels containing $0.1 \% \quad \mathrm{NaDodSO}_{4} \quad\left(\mathrm{NaDodSO}_{4} / \mathrm{PAGE}\right)$ according to Laemmli (1970). The $\mathrm{M}_{\mathrm{r}}$ of the recombinant perforin-like protein (termed r-Perforin) was $24 \mathrm{kDa}$, as expected. The protein was dialyzed against artificial seawater.
Table 2. Suberites domuncula. Antibacterial activities of sponge- (SB) and primmorph-associated bacteria $(\mathrm{PB})$. Inhibition zones are in $\mathrm{mm} \pm \mathrm{SE}(\mathrm{n}=3)$. -: no inhibition zone. Isolates SB3, SB4, SB5 and PB2 did not show any activity. None of the isolates were active against the reference vicinity bacteria (VB) strains VB6, VB7 and VB8

\begin{tabular}{|lccccc|}
\hline \multirow{2}{*}{$\begin{array}{l}\text { Reference } \\
\text { strains }\end{array}$} & $\alpha$-Proteobacterium & $\alpha$-Proteobacterium & \multicolumn{3}{c|}{ Idiomarina } \\
& SB1 & SB2 & SB6 & PB1 \\
\hline VB1 & $4.3 \pm 0.5$ & $2.6 \pm 1.1$ & $2.3 \pm 0.5$ & $3.3 \pm 0.3$ \\
VB2 & - & - & $5.6 \pm 0.5$ & - \\
VB3 & - & - & $2.6 \pm 1.1$ & - \\
VB4 & - & $2.3 \pm 0.5$ & $4 \pm 0$ & - \\
VB5 & - & - & $1 \pm 1.0$ & - \\
& & & & & \\
\hline
\end{tabular}

\section{RESULTS AND DISCUSSION}

\section{Antibacterial activity of sponge and its associated bacteria}

Organic extracts obtained from the sponge displayed strong antibacterial activity (Table 1). Suberites domuncula produces a neurotoxin called suberitine which displays hemolytic/toxic activities (Böhm et al. 2001). It is conceivable that this protein toxin might also be responsible for the observed antimicrobial activities. The sponge extract inhibited growth of sponge vicinity bacteria. However, some of the bacterial strains isolated from sponge surface were sensitive to the sponge extract. Similar observation has also been made by Newbold et al. (1999). They opined that co-occurring bacteria might have

Table 1. Suberites domuncula. Antibacterial activity of sponge and primmorph extracts. Inhibition zones are in $\mathrm{mm} \pm$ $\mathrm{SE}(\mathrm{n}=3)$. VB: vicinity bacteria that were isolated from the vicinity of the sponges; SB: sponge-associated bacteria that were isolated from the sponge surface; PB: primmorphassociated bacteria. -: no inhibition zone

\begin{tabular}{|lcc|}
\hline Reference strains & Sponge extract & Primmorph extract \\
\hline VB1 & $5.7 \pm 0.6$ & $12.5 \pm 1.2$ \\
VB2 & $5.3 \pm 1.2$ & $13.0 \pm 1.4$ \\
VB3 & $5.7 \pm 0.6$ & $14.0 \pm 1.5$ \\
VB4 & $4.7 \pm 1.2$ & - \\
VB5 & - & $9.5 \pm 0.9$ \\
VB6 & $1.0 \pm 0.4$ & $4.5 \pm 0.8$ \\
VB7 & - & $10.5 \pm 1.1$ \\
VB8 & - & - \\
SB1 & - & $11.0 \pm 1.8$ \\
SB2 & - & - \\
SB3 & - & - \\
SB4 & -0.6 & - \\
SB5 & $5.7 \pm 2.9$ & - \\
SB6 & $8.0 \pm 1.7$ & $4.0 \pm 1.3$ \\
PB1 & - & $2.5 \pm 0.8$ \\
PB2 & - & $5.0 \pm 1.2$ \\
& & \\
\hline
\end{tabular}

influenced the evolution of secondary metabolites in some sponge taxa.

There is ample evidence documenting the existence of bacteria associated with sponges and their possible interaction with the host. Sponge-associated bacteria play an important role in the production of antibacterial metabolites (Kobayashi \& Ishibashi 1993, Thakur \& Anil 2000). However, most previous studies focused on the bacteria isolated from whole sponge or from the mesohyl (Kobayashi \& Ishibashi 1993 and references cited herein, Hentschel et al. 2001). The present study was an attempt to investigate the hypothesis of an epibacterial chemical defense of the sponge Suberites domuncula by considering its surface-associated bacteria. Altogether, 3 isolates with antibacterial activity were identified from the sponge surface (Table 2). These results highlight the importance of these bacteria in the antibacterial activity of host.

\section{Antibacterial activity of primmorphs and their associated bacteria}

As the sponge as well as its associated bacteria exhibit antibacterial activity, the determination of the origin of active metabolites (sponge and/or bacteria) became complicated. One possible way to ascertain the origin is to separate these 2 partners and test their activity individually. In the light of this, we developed sponge primmorphs in vitro to eliminate the associated bacteria. It was observed that primmorph extracts also exhibit antibacterial activity (Table 1). Interestingly, the activity of the primmorph extract was stronger than that of the sponge extract when used at a lower concentration (primmorph extracts were tested at a lower concentration because only a limited number of primmorphs were available for extraction).

Primary cell culture of sponge Suberites domuncula was developed in the laboratory under sterile condi- 
tion. However, we did not succeed in eliminating some of the sponge-associated bacteria. The presence of bacteria in sponge and its primmorphs was traced by using bacterial rRNA, and the results showed that the bacterial population was present even after dissociation of sponge cells. As a further step, 2 bacterial strains were isolated and cultured from the primmorphs. Interestingly, both the bacterial isolates displayed antibacterial activity (Table 2).

\section{Autoinhibition of sponge- and primmorph-associated bacteria}

Apart from deterring sponge vicinity bacteria, some of the sponge- and primmorph-associated bacteria selectively inhibited the growth of their neighbors (Table 3). These results might indicate that antibacterial metabolites confer a selective advantage to the producer for competition with other bacteria, populating the same ecological niche. The isolates SB1, SB6, PB1 and PB2 displayed autoinhibition (Table 3). This phenomenon has been reported for marine Pseudoalteromonas and Alteromonas (Holmström \& Kjelleberg 1999), pathogenic Pseudomonas (Xiong et al. 1994) and marine Chromobacterium/ Pseudomonas (Anderson 1974, Gauthier 1975). However, it does not appear to be widely distributed among genera of other marine microorganisms (Nair \& Simidu 1987). Earlier researchers suggested that in some bacteria, the production of autotoxic compounds is important for inhibiting their further growth in dense culture.

\section{Phylogenetic identification of bacteria}

Partial 16S rDNA sequences were obtained from PCR products for phylogenetic identification (Table 4). Although precise phylogenetic identification from partial sequences is limited, they provide sufficient information for a first assessment. The isolates SB1 and SB2 show species-level similarity (>98.0\%) to the $\alpha$-Proteobacterium MBIC3368. Interestingly, this bacterium has been isolated from several different sponges. Webster \& Hill (2001) reported that the $\alpha$-Proteobacterium MBIC3368 strain NW001 dominates the culturable microbial community of the Australian sponge Rhopaloeides odorabile. The $\alpha$ Proteobacterium MBIC3368 strain SB89 was also recovered from the Mediterranean sponge Aplysina aerophoba, which displayed antimicrobial activity against various Gram-positive and Gram-negative bacteria (Hentschel et al. 2001). Additionally, a gene bank entry reports on the isolation of the $\alpha$-Proteobacterium MBIC3368 from an unidentified sponge (Genbank Accession Number AB012864). Apparently, the $\alpha$-Proteobacterium MBIC3368 is frequently associated with diverse marine sponges irrespective of their taxonomic identity, geographic location or natural products profile. 16S rDNA sequence analysis of the isolate SB6 revealed species-level similarity to Idiomarina loihiensis (Alteromonadaceae) (98.8\%). Marine alteromonads are well known to be abundant producers of antimicrobial compounds (Holmström \& Kjelleberg 1999). Therefore, these findings are not unexpected.

Table 3. Suberites domuncula. Autoinhibition of sponge- (SB) and primmorph-associated bacteria (PB). Inhibition zones are in $\mathrm{mm} \pm \mathrm{SE}(\mathrm{n}=3) .-$ : no inhibition zone. Isolates SB3, SB4 and SB5 did not show any activity

\begin{tabular}{|c|c|c|c|c|c|}
\hline $\begin{array}{l}\text { Reference } \\
\text { strains }\end{array}$ & $\begin{array}{c}\alpha \text {-Proteobacterium } \\
\text { SB1 }\end{array}$ & $\begin{array}{c}\alpha \text {-Proteobacterium } \\
\text { SB2 }\end{array}$ & $\begin{array}{l}\text { Idiomarina } \\
\quad \text { SB6 }\end{array}$ & $\begin{array}{c}\text { Pseudomonas } \\
\text { PB1 }\end{array}$ & $\begin{array}{c}\text { Pseudomonas } \\
\text { PB2 }\end{array}$ \\
\hline SB1 & $1.6 \pm 0.6$ & - & $3.7 \pm 1.8$ & $2.3 \pm 0.6$ & - \\
\hline SB2 & - & - & - & $2.3 \pm 0.6$ & - \\
\hline SB6 & - & $2 \pm 1.0$ & $3.0 \pm 1.3$ & - & - \\
\hline PB1 & - & - & - & $4.3 \pm 0.6$ & $4 \pm 1.0$ \\
\hline PB2 & - & - & - & $3.6 \pm 0.6$ & $4.3 \pm 0.6$ \\
\hline
\end{tabular}

Table 4. Suberites domuncula. Phylogenetic identification of sponge- (SB) and primmorph-associated bacteria (PB)

\begin{tabular}{|lccccc|}
\hline Isolate & Method & $\begin{array}{c}\text { Bases sequenced } \\
\text { (bp) }\end{array}$ & Nearest phylogenetic neighbor & $\begin{array}{c}\% \text { similarity } \\
\text { Phylogenetic } \\
\text { affiliation }\end{array}$ \\
\hline SB1 & PCR product & 465 & $\alpha$-Proteobacterium MBIC 3368 & 98.9 & $\alpha$-Proteobacteria \\
SB2 & PCR product & 398 & $\alpha$-Proteobacterium MBIC 3368 & 98.5 & $\alpha$-Proteobacteria \\
SB6 & PCR product & 379 & Idiomarina loihiensis & 98.9 & $\gamma$-Proteobacteria \\
PB1 & Cloned & 1453 & Unidentified Pseudomonas sp. & 94.5 & $\gamma$-Proteobacteria \\
PB2 & Cloned & 1458 & Unidentified Pseudomonas sp. & 94.4 & $\gamma$-Proteobacteria \\
\hline
\end{tabular}


The 16S rDNA genes of the primmorph Isolates PB1 and PB2 were cloned, sequenced nearly completely ( $>1350 \mathrm{bp}$ ) and deposited in GenBank with preliminary accession numbers AF482708 for PB1 and AF482707 for PB2. Considering that the genus Pseudomonas is phylogenetically well characterized, the sequence similarities to the nearest phylogenetic neighbor are remarkably low (94 to $95 \%$ ). Also, both isolates cannot be grown on B1 agar plates after repeated subculture. It is conceivable that they require specific, possibly host-derived factors for sustained growth that are missing in standard laboratory media. Interestingly, the construction of $16 \mathrm{~S}$ rDNA libraries from aquarium-maintained Suberites domuncula revealed only 1 sequence type, which also belonged to the genus Pseudomonas (Böhm et al. 2001). This study provides further evidence that Pseudomonas bacteria may be symbiotically associated with $S$. domuncula sponges. As the PB1 and PB2 isolates represent novel species, they are valid candidates for the production of novel antimicrobial compounds.

\section{Production of an antibacterially active perforin-like protein}

A cDNA clone was isolated that resembles human perforin and displayed antibacterial activity. Human perforin is found in lytic granules of cytotoxic natural killer and T-cells (Lowin et al. 1994). After release, perforin forms pores in the target cell membranes, initiating osmotic lysis. Hence, perforin is an effector molecule of the nonspecific cytotoxic T-lymphocytemediated defense system of mammalians. Perforin displays direct or indirect toxic effects during fungal infection in humans (Henkart et al. 1995), protozoanmediated cytotoxicity (Zhou et al. 2001) as well as during bacterial infection (Nickell \& Sharma 2000).

The cDNA was $839 \mathrm{nt}$ long (accession number AJ307008). One open reading frame was present, which spans from nt 31 to $\mathrm{nt}_{624}$ (Fig. 1A). The estimated size of the polypeptide is $22660 \mathrm{Da}$ (PC/GENE 1995; Physchem). The instability index was computed with 44.39, suggesting that this polypeptide belongs to the

\section{Thin-layer chromatography (TLC)}

Previous efforts with Suberites domuncula indicated that the sponge as well as its primmorphs can produce a hemolytic protein 'suberitine'. In the present investigation, as the antibacterial activity of functional sponge was retained in the primmorphs, we performed TLC on both the extracts. The results showed similar profiles between sponge and primmorph extracts (data not shown). Four major spots were observed, which were characterized by the following $R f$ values: 0.22 , $0.31,0.63$ and 0.83 . It remains to be investigated whether the primmorph cells of $S$. domuncula are also capable of producing the active metabolites that are normally produced by the intact sponge. This study emphasizes the possibility of establishing primmorph cultures with its associated bacteria for the production of bioactive compounds in vitro. If sponge primmorph cultures can produce bioactive metabolites, similar or identical to those produced by functional sponge, they will be useful model systems to explore a wider application in the production of sponge secondary metabolites in vitro.
A SDPFL GGCACGAGAAAAAACGAACCGCTTATTGAGATGGGTGTGCTTCGATTGGTCATATACGTT 60 $\begin{array}{lllllllllllll}\text { PFL SD } & M & G & V & \text { L } & R & \text { L } & \text { V } & I & Y & V & 10\end{array}$ SDPFL GTCTTTTATGCAACGCTAGCCTCTGCTCATTCGCCATGTGAAACAAATTCTTGTTGTAAT 120 $\begin{array}{llllllllllllllllllllll}\text { PFL SD } & V & F & Y & A & T & L & A & S & A & H & S & P & C & E & T & N & S & C & C & N & 30\end{array}$ SDPFL GGTGCAACATGTCGTGACACCTCTTCATACACATGTTCTTGTCGATCTGGTTACAGCGGA 180 $\begin{array}{llllllllllllllllllllll}\text { PFL SD } & G & A & T & C & R & D & T & S & S & Y & T & C & S & C & R & S & G & Y & S & G & 50\end{array}$ SDPFL ACATACTGTCAGAACCCTTTTGGTCGACTTACCTTTTACGCTCGTTATGGCCATGGTCTT 240 $\begin{array}{lllllllllllllllllllllll}\text { PFL SD } & T & Y & C & Q & N & P & F & G & R & L & T & F & Y & A & R & Y & G & H & G & L & 70\end{array}$ SDPFL CCTGACGAAGATGGGTGGTGAATGATAGTGACCCCTACATGGAGATAATTGCTTATTAT 300 $\begin{array}{lllllllllllllllllllllll}\text { PFL SD } & P & D & E & D & G & W & W & N & D & S & D & P & Y & M & E & I & I & A & Y & Y & 90\end{array}$ SDPFL CGAGGGGTAGCATACGCCATACAACAAGCACTAGAAATGGAGATCATAGCCCAGTCTGG 360 $\begin{array}{llllllllllllllllllllll}\text { PFL_SD } & R & G & G & S & I & R & H & T & T & S & T & R & N & G & D & H & S & P & V & \text { W } & 110\end{array}$ SDPFL CACCAGAATATTGACTTTGGTAGGCGGATTGGACACGTTTCACTGTTCGTGTGTGGGAT 420 $\begin{array}{lllllllllllllllllllllll}\text { PFL SD } & H & \& & N & I & D & F & G & R & R & D & W & T & R & F & T & V & R & V & W & D & 130\end{array}$ SDPFL AGTGACAATAATGCAGATGATGCGCTGTCAAGCACCGGTACATACGGTTTAAGTTCTCAC 480 $\begin{array}{llllllllllllllllllllll}\text { PFL SD } & \text { S } & \text { D } & \text { N } & \text { N } & \text { A } & \text { D } & \text { D } & \text { A } & \text { L } & \text { S } & \text { S } & \text { T } & \text { G } & \text { T } & \text { Y } & \text { G } & \text { L } & \text { S } & \text { S } & \text { H } & 150\end{array}$ SDPFI ACTTCAAATACCATGGTGAAGATGAACTGCTACAGTGGATACGTTTATTTTGACTACCAC 540 $\begin{array}{llllllllllllllllllllll}\text { PFL SD } & T & S & N & T & M & V & K & M & N & C & Y & S & G & Y & V & Y & F & D & Y & H & 170\end{array}$ SDPF'L TTTCAGCCAGGATTTGCTTGGAGTAGTGGAGCCGTGCACTTGAACTATGATTACAAACTG 600 $\begin{array}{llllllllllllllllllllll}\text { PFL_SD } & F & \& & P & G & F & A & W & S & S & G & A & V & H & L & N & Y & D & Y & K & L & 190\end{array}$ SDPFL TATAATATTACGATTCTTGTTATTAATGTGTGCAGAACCTTTCCAGTTGTATAAAACAT 660 $\begin{array}{lllllllllll}\text { PFL_SD } & Y & N & Y & Y & D & \text { S } & C & Y & - & 198\end{array}$ SDPF'L TAATATGCATGGTGTATTGTTATTATGGAAGTTTCATCTTGGAACATCGGTGTTGTG 720 SDPFL AGTGTAAGATTTCTTTTGTTGATCTATTAACATTGTATGAGTATTCAATTTGTATGCTTT 780 SDPFL CCATTCATCTGTACAATTATTAGCTTTGTCTTGGAATTTGTTCTTTATAACTCTATGA 839

\section{B}

Suberites domuncula: Perforin-like protein

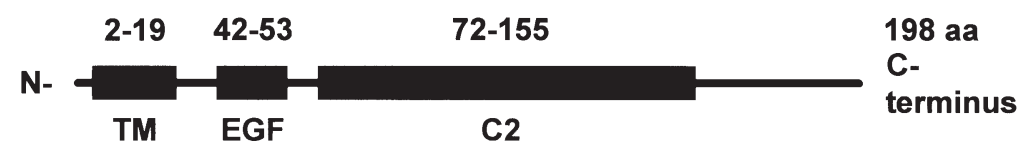

Fig. 1. Suberites domuncula. (A) The nucleotide sequence (SDPFL) and the deduced polypeptide of the putative perforin-like protein (termed PFL_SD). (B) Domain organization of the perforin-like protein. A transmembrane (TM) region is predicted close to the N-terminus of the protein, followed by the potential EGF-like domain cysteine pattern signature (EGF) and the C2 domain (C2). Total protein length is 198 aa 
class of unstable proteins. The perforin-like protein from Suberites domuncula does not contain a predictable eukaryotic secretory signal sequence. The domains present in the sponge perforin-like protein were predicted (ISREC 2001) (Fig. 1B). One EGF-like domain cysteine pattern signature is present from $\mathrm{aa}_{42}$ to $\mathrm{aa}_{53}$ in the deduced polypeptide. This domain is less conserved in a series of metazoan proteins and is predominantly found in membrane-bound proteins and in secreted molecules (Campbell \& Bork 1993). Furthermore, a C2 domain, with lower similarity, between $\mathrm{aa}_{72}$ to $\mathrm{aa}_{155}$ is present; the $\mathrm{C} 2$ domain is thought to be involved in $\mathrm{Ca}^{2+}$-dependent phospholipid binding (Davletov \& Suedhof 1993). Highest sequence similarity of the sponge deduced polypeptide was found in the databases with the human preforming protein, perforin I (accession number NP_005031). The membrane attack complex components signature of perforin is not present in the sponge protein. The 'expect value' $(E)$ between the sponge molecule and the human perforin is $7 \mathrm{e}-04$, suggesting statistical significance. One potential transmembrane region was predicted, which spans from $\mathrm{aa}_{2}$ to $\mathrm{aa}_{19}$ i the domain putative organization of the sponge perforin-like protein is shown in Fig. 1.

A Northern blot experiment revealed that the gene encoding the perforin-like protein was not expressed in dissociated cells from Suberites domuncula. However, after 3 and $6 \mathrm{~d}$, the transcript became increasingly visible in the primmorphs (data not shown). The transcript was $0.9 \mathrm{~kb}$, indicating that the full-length clone has been isolated. Additionally, the recombinant

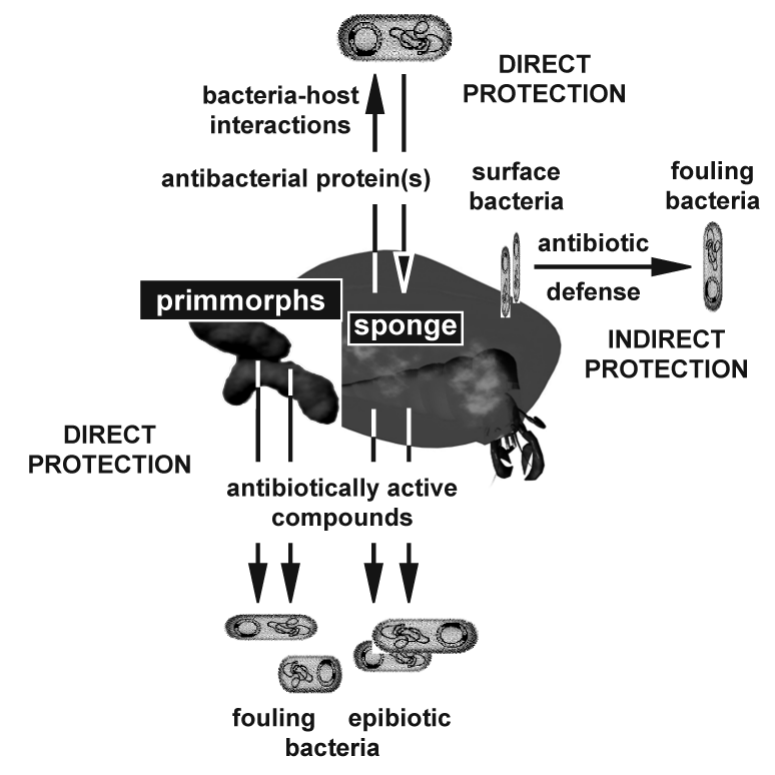

Fig. 2. Suberites domuncula. A direct and indirect epibacterial defense hypothesis perforin protein displayed antimicrobial activity, while the control supplemented with a recombinant putative AF protein (rAF_GEOCY) did not. The sponge Tethya lyncurium synthesizes a pore-forming protein (Mangel et al. 1992), which is of similar size to other poreforming toxins, e.g. the Escherichia coli hemolysin (Bhakdi et al. 1986). Future studies will likely elucidate the exact role of this potentially novel class of sponge protein toxins. These data provide additional evidence that sponges are provided with the capacity to synthesize antibacterially active proteins.

\section{A model for epibacterial chemical defense of Suberites domuncula}

The cumulative data of this contribution show that Suberites domuncula is provided with an array of protection strategies against bacteria (Fig. 2). This sponge produces antibacterial compounds for protection against bacterial epibiosis; this can be considered as a direct defense strategy. $S$. domuncula also harbors antimicrobially active bacteria on its surfaces, which might help the sponge indirectly in the epibacterial defense. Moreover, S. domuncula has a capacity to produce a perforin-like antibacterial protein. This investigation highlights the importance of the sponge S. domuncula and its associated bacteria as a valuable resource for the discovery of novel antimicrobials as well as the possible use of sponge primary cell culture (primmorphs) technique for the production of bioactive metabolites.

Acknowledgements. We are grateful to Dr. E. Desa (Director of the National Institute of Oceanography in Goa) and to Dr. N. B. Bhosle for their support and encouragement. Thanks are also due to Ms. R. Steffen for help in primmorph cultivation. N.T. acknowledges the DAAD (Germany) for a short-term fellowship award and the CSIR (India) for a senior research fellowship award. This work was supported by the BMBF Kompetenzzentrum 'BIOTEC-MARIN' to W.E.G.M. (F0345A) and to U.H. (F0345E), the European Commission (project: SPONGE) and the International Human Frontier Science Program (RG-333/96-M). The NIO contribution number is 3800 .

\section{LITERATURE CITED}

Althoff K, Schütt C, Steffen R, Batel R, Müller WEG (1998) Evidence for a symbiosis between bacteria of the genus Rhodobacter and the marine sponge Halichondria panicea: harbor also putatively toxic bacteria. Mar Biol 130: $529-536$

Anderson RJ, Wolfe MS, Faulkner DJ (1974) Autotoxic antibiotic production by a marine Chromobacterium. Mar Biol 27:281-285

Bergquist PR (1978) Sponges. University of California Press, Berkeley 
Bhakdi S, Mackman N, Nicaud JM, Holland IB (1986) Escherichia coli hemolysin may damage target cell membranes by generating transmembrane pores. Infect Immun 52:63-69

Böhm M, Hentschel U, Friedrich AB, Fieseler L, Steffen R, Gamulin V, Müller IM, Müller WEG (2001) Molecular response of the sponge Suberites domuncula to bacterial infection. Mar Biol 139:1037-1045

Campbell ID, Bork P (1993) Epidermal growth factor-like modules. Curr Opin Struct Biol 3:385-392

Cariello L, Tosti E, Zanetti L (1982) The hemolytic activity of suberitine. Comp Biochem Physiol C 73:91-93

Davletov BA, Suedhof TC (1993) A single C2 domain from synaptotagmin I is sufficient for high affinity $\mathrm{Ca}^{2+} /$ phospholipid binding. J Biol Chem 268:26386-26390

Elyakov GB, Kutznetsova TA, Mikhailov VV (1996) From chemistry of marine natural products to marine technologies: research at pacific institute of bioorganic chemistry. Mar Tech Soc J 30:21-28

Friedrich AB, Fischer I, Proksch P, Hacker J, Hentschel U (2001) Temporal variations of the microbial community associated with the Mediterranean sponge Aplysina aerophoba. FEMS Microbiol Ecol 38:105-113

Gauthier MJ, Shewan JM, Gibson DM, Lee JV (1975) Taxonomic position and seasonal variations in marine neritic environment of some gram-negative antibiotic-producing bacteria. J Gen Microbiol 87:211-218

Haygood MG, Schmidt EW, Davidson SK, Faulkner DJ (1999) Microbial symbionts of marine invertebrates: opportunities for microbial biotechnology. J Mol Microbiol Biotechnol 1:33-43

Henkart PA, Williams MS, Nakajima H (1995) Degranulating cytotoxic lymphocytes inflict multiple damage pathway on target cells. In: Griffith GM, Tschopp J (eds) Pathways for cytolysis. Springer-Verlag, Berlin, p 75-99

Hentschel U, Schmid M, Wagner M, Fieseler L, Gernert C, Hacker J (2001) Isolation and phylogenetic analysis of bacteria with antibacterial activities from the Mediterranean sponge Aplysina aerophoba and Aplysina cavernicola. FEMS Microb Ecol 35:305-312

Holmström C, Kjelleberg S (1999) Marine Pseudoalteromonas species are associated with higher organisms and produce biologically active extracellular agents. FEMS Microb Ecol 30:285-293

Kobayashi J, Ishibashi M (1993) Bioactive metabolites from symbiotic marine microorganisms. Chem Rev 93: 1753-1769

Krasko A, Batel R, Schröder HC, Müller IM, Müller WEG (2000) Expression of silicatein and collagen genes in the marine sponge Suberites domuncula is controlled by silicate and myotrophin. Eur J Biochem 267:4878-4887

Kruse M, Müller IM, Müller WEG (1997) Early evolution of metazoan serine/threonine- and tyrosine kinases: identifi-

Editorial responsibility: John Dolan,

Villefranche-sur-Mer, France cation of selected kinases in marine sponges. Mol Biol Evol 14:1326-1334

Laemmli UK (1970) Cleavage of structural proteins during the assembly of the head of bacteriophage T4. Nature 227: $680-685$

Lowin B, Hahne M, Mattmann C, Tschopp J (1994) Cytolytic T-cell cytotoxicity is mediated through perforin and Fas lytic pathway. Nature 370:650-652

Mangel A, Leitao JM, Batel R, Zimmermann H, Müller WEG, Schröder HC (1992) Purification and characterization of a pore-forming protein from the marine sponge Tethya lyncurium. Europ J Biochem 210:499-507

Müller WEG, Wiens M, Batel R, Steffen R, Schröder HC, Borojevic R, Custodio MR (1999) Establishment of a primary cell culture from a sponge: primmorphs from Suberites domuncula. Mar Ecol Prog Ser 178:205-219

Nair S, Simidu U (1987) Distribution and significance of heterotrophic marine bacteria with antibacterial activity. Appl Environ Microbiol 53:2957-2962

Newbold RW, Jensen PR, Fenical W, Pawlik JR (1999) Antimicrobial activity of Caribbean sponge extracts. Aquat Microb Ecol 19:279-284

Nickell SP, Sharma D (2000) Trypanosoma cruzi: roles for perforin-dependent and perforin-independent immune mechanisms in acute resistance. Exp Parasitol 94:207-216

Rao JKM, Argos P (1986) A conformational preference parameter to predict helices in integral membranes proteins. Biochim Biophys Acta 869:197-214

Rützler K (1985) Associations between Caribbean sponges and photosynthetic organisms. In: Rützler K (ed) New perspectives in sponge biology. Smithsonian Institution Press, Washington, DC, p 455-466

Thakur NL, Anil AC (2000) Antibacterial activity of the sponge Ircinia ramosa: importance of its surface associated bacteria. J Chem Ecol 26:57-71

Vacelet J (1975) Étude en microscopie électronique de l'association entre bactéries et spongiaires du genre Verongia (Dictyoceratida). J Microsc Biol Cell 23:271-288

Wahl M, Jensen PR, Fenical W (1994) Chemical control of bacterial epibiosis on Ascidians. Mar Ecol Prog Ser 110: $45-57$

Webster NS, Hill RT (2001) The culturable microbial community of the Great Barrier Reef sponge Rhopaloeides odorabile is dominated by a $\alpha$-proteobacterium. Mar Biol 138: 843-851

Wilkinson CR (1992) Symbiotic interactions between marine sponges and algae. In: Reisser W (ed) Algae and symbioses. Biopress, Bristol, p 112-151

Xiong G, Struckmeier M, Lutz F (1994) Pore-forming Pseudomonas aeruginosa cytotoxin. Toxicology 87:69-83

Zhou P, Freidag BL, Caldwell CC, Seder RA (2001) Perforin is required for primary immunity to Histoplasma capsulatum. J Immunol 166:1968-1974

Submitted: August 22, 2002; Accepted: November 19, 2002

Proofs received from author(s): January 14, 2003 